\section{Concordance between vascular plant and macrofungal community composition in broadleaf deciduous forests in central Italy}

\author{
Marco Landi ${ }^{(1-2)}$, Elena Salerni ${ }^{(2)}$, Elia Ambrosio ${ }^{(2)}$, Maria D'Aguanno ${ }^{(2)}$, \\ Alessia Nucci ${ }^{(2)}$, Carlo Saveri ${ }^{(1)}$, Claudia Perini ${ }^{(2)}$, Claudia Angiolini ${ }^{(2)}$
}

We examined the concordance between vascular plants and macrofungi (grouped into trophic groups) in Mediterranean forest habitats (central Italy). Our goal was to test how consistently plant and fungi groups classify plots in a broadleaf deciduous forest dominated by Quercus cerris. Our hypothesis was that groups of plants can be used as surrogates for the classification of macrofungal communities. The test of concordance comprised two steps: (1) the plant species data sets were subjected to cluster analysis, to obtain three classifications based on presence of all plants, presence and frequency of only woody species; (2) Multiple Response Permutation Procedures (MRPP) was used to test the performance of each plant classification applied to the fungi data sets. Sample scores on the first PCA axis were used to investigate the relationships between compositional patterns. In the concordance analysis, the classification based on woody plants only provided better results than the classification obtained using both herbaceous and woody plants. Cross-tests gave the best results when the "woody plants" classification was applied to ectomycorrhizal fungi (EMF) and, to a certain extent, to humicolous saprotrophs (Sh). The ordination analysis suggested that the frequency of woody plants follows a similar spatial distribution to EMF and Sh fungal groups and is therefore expected to covariate along the same environmental gradients. Many EMF exhibit preferences for few (one or two) hosts. Significant associations were found among numerous EMF and woody plant species. Woody plants such as Sorbus domestica and Prunus spinosa appear to be associated with many EMF. The combination of a high frequency of Fraxinus oxycarpa and Quercus petraea seems to promote distinct assemblages of EMF and Sh fungi. Characteristic assemblages of fungi were found in association with certain tree and shrub combinations.

Keywords: Deciduous Oaks, Ectomycorrhizal Fungi, Host Specificity, Saprotrophic Fungi, Surrogates, Trophic Groups

\section{Introduction \\ Finding strategies to identify the state of biodiversity and to develop appropriate con- servation and monitoring programs is one of the most important issues in the field of eco- logy (Gaston 2000, Berglund \& Jonsson 2001, Similä et al. 2006). The growing im- pact of human activities that contribute to habitat fragmentation and decrease diversity}

on natural ecosystems has brought with it an urgent need for the development of simple, quick and cost-effective methodologies for quantifying and monitoring changes in biological diversity (Berglund \& Jonsson 2001, Heino \& Mykrä 2006, Santi et al. 2010).

Surrogate species, whose primary purpose is to ascertain and test which groups of organisms reflect the diversity of others, can be

$\square$ (1) Ufficio Territoriale per la Biodiversità di Siena, Corpo Forestale dello Stato, v. Cassia Nord 7, I-53100 Siena (Italy); (2) Department of Life Sciences, University of Siena, v. P.A. Mattioli 4, I-53100 Siena (Italy)

@ Claudia Perini (claudia.perini@unisi.it)

Received: Dec 10, 2013 - Accepted: May 15, 2014

Citation: Landi M, Salerni E, Ambrosio E, D’Aguanno M, Nucci A, Saveri C, Perini C, Angiolini $C, 2015$. Concordance between vascular plant and macrofungal community composition in broadleaf deciduous forests in central Italy. iForest 8: 279-286 [online 2014-08-22] URL: http: / / www.sisef.it/iforest/contents/?id=ifor1199-008

Communicated by: Alberto Santini of great help in quantifying biological diversity for less well-known groups and less easily detectable taxa (Pharo et al. 1999, Schmit et al. 2005, Öster 2008, Qian \& Ricklefs 2008). Moreover, the possibility of high congruence between different taxa, which is extremely interesting from an ecological viewpoint, can reduce the time and costs necessary for planning conservation actions, although no single biotic group shows a perfect match with any other. The "taxon surrogacy" hypothesis (Ryti 1992) is based on the assumption of concordance among species richness or patterns of community composition across different taxonomic groups (Virolainen et al. 2000, Su et al. 2004). Nevertheless, the selection of surrogate taxonomic groups is not straightforward, and different methods have been applied by various authors. In fact, over the last 20 years, conservation biologists have discussed the use of surrogate species in conservation planning at great length, debating both the advantages and disadvantages of this approach (Murphy et al. 2011). There are several different types of surrogacy (Magurran 2004), such as: (i) cross-taxon, where high species richness in one taxon is used to infer high species richness in others (Mortiz et al. 2001); (ii) within-taxon, where generic or familial richness is treated as a surrogate of species richness (Balmford et al. 1996); and (iii) environmental, where parameters such as temperature or topographical diversity are assumed to reflect species richness (Magurran 2004). Another approach is based on "community concordance" and describes the degree to which patterns in community structure in a set of sites are similar in two different taxonomic groups (Paszkowski \& Tonn 2000). This method has been applied rarely, and mainly in aquatic ecosystems (Paszkowski \& Tonn 2000, Paavola et al. 2003, Heino \& Mykrä 2006, Landi et al. 2012).

According to various authors, vascular flora has a great potential to determine the diversity of other groups because it constitutes the bulk of total biomass and provides physical structure for other ecosystem components (fauna and ecological processes) through the establishment of vegetation (Ryti 1992, Young 2000, Öster 2008). In addition, a long tradition and much experience has been gained in the sampling of vascular plants, relatively easy to perform, and plant taxonomy is sufficiently well described and standardized as well (Sætersdal et al. 2003, Chiarucci et al. 2005, Schmit et al. 2005). Because fungi are heterotrophic organisms mainly dependent on vascular plants, the existence of a relationship between the composition of plant and fungal communities has been hypothesized (Chiarucci et al. 2005). Coherently, consistent correlations have 
been found between macrofungi and patterns of vascular plants (Brussaard et al. 2001, Packham et al. 2002). However, among the taxa investigated macrofungi are generally overlooked and rarely considered in reserve planning because of their small size, their ephemeral fruit bodies, their difficult identification, and the paucity of expertise concerning their taxonomy and ecology (Hawksworth 1991, Chiarucci et al. 2005, McMullan-Fisher et al. 2009). Nevertheless, their inclusion in conservation planning and management is important because of their vita functional roles in ecosystems (Lodge et al 2004, Öster 2008, McMullan-Fisher et al 2009) and their great richness estimated worldwide (Hawksworth 2001). However, while at large spatial scales communities with high tree-species richness have been found to have correspondingly high macrofungal species richness (Schmit et al. 2005), low correlations have been found at local scales (e.g., Virolainen et al. 2000, Sætersdal et al. 2003, Similä et al. 2006, Santi et al 2010).

In this investigation we examined the concordance between vascular plants (grouped as woody plants and all plants) and macrofungi (grouped into trophic groups) at the local scale, within two nature reserves in $\mathrm{Me}$ diterranean forest habitats. To our knowledge, this is a new approach to specifically test the concordance between vascular plant and macrofungi communities in broadleaf deciduous forests. Our primary goal was to test how consistently plant and fungi groups classify plots in broadleaf deciduous forest ecosystems. We hypothesized that plot grouping based on plant species can be used as a surrogate for the classification of macrofungal communities. We also investigated the association between plant and fungi species for data sets showing a significant concordance, through the analysis of correlation coefficients, to ascertain whether plant community composition could be used as an "ecological indicator" for specific groups of fungi. This information will improve managers' ability to plan effectively for the presence of these important macrofungal resources in deciduous forest ecosystems.

\section{Materials and methods}

\section{Study site}

The study was carried out in two nearby temperate deciduous broadleaf forests characterized by Quercus cerris, widely dominant in the canopy layer, followed by Fraxinus ornus and $Q$. pubescens. The number of trees with diameter at breast height $(\mathrm{DBH})>$ $2 \mathrm{~cm}$ ranged from 7 to 33 trees per $100 \mathrm{~m}^{2}$. The mean density of trees was $17 \pm 7$ (SD) per $100 \mathrm{~m}^{2}$.

These sites are located in Tuscany (central Italy), within the State Nature Reserves of
Palazzo $\left(43^{\circ} 20^{\prime} \mathrm{N}, 11^{\circ} 04^{\prime} \mathrm{E}\right)$ and Cornocchia $\left(43^{\circ} 23^{\prime} \mathrm{N}, 11^{\circ} 10^{\prime} \mathrm{E}\right)$. The reserves cover about 800 ha of meadows and pastures on hillsides, with a slope of about 15-25 degrees and elevation from 330 to $530 \mathrm{~m}$ a.s.l. The two areas are similar in terms of bedrock (limestone, sandstone and siltstone), nearneutral soils, and forest type, composition and density. No logging or harvesting have been carried out in either reserve in the last 40 years. The climate is Mediterranean and characterized by a dry summer and rain in spring and autumn; the hottest months are July-August and the coldest January-February. The mean annual precipitation is approximately $800 \mathrm{~mm}$ and the mean annual temperature is $13.5^{\circ} \mathrm{C}$ at the nearest meteorological station (Pentolina), situated $450 \mathrm{~m}$ a.s.l. (ARSIA data for the period 1992-2006).

Such sites provide a good location to study the relationships between fungal and plant communities since mushroom gathering and timber extraction are not permitted. In addition, they represent fairly well the type of native forest common in the Mediterranean basin and notoriously rich in fungi (Onofri et al. 2005, Salerni \& Perini 2007).

\section{Sampling design and recording of plants and fungi}

Thirty $100 \mathrm{~m}^{2}$ permanent plots $(10 \times 10 \mathrm{~m}$, marked by metal stakes in each corner) were randomly placed in the deciduous broadleaf forests (fifteen for each reserve). The plots were previously identified and mapped (scale 1:5000) by photo-interpretation, with a buffer zone of about $20 \mathrm{~m}$ around each polygon to reduce possible edge effects. Data were collected in each plot for all vascular plants (presence-absence), woody plants and fungal species (presence-absence and frequency). As for vascular plants, herbs, seedlings, shrubs and trees were sampled. Woody species frequency was obtained by counting the number of individuals per species per plot, including trees or shrubs with $\mathrm{DBH}>2$ $\mathrm{cm}$ or height $>2 \mathrm{~m}$. Macrofungi were identified based on morphology with the help of general analytic keys and monographs (Salerni et al. 2010). To quantify their abundance, their frequency was recorded as the number of carpophores (fruiting bodies) $>1$ $\mathrm{mm}$ per species in each plot (Arnolds 1981). Although above-ground fruiting bodies do not necessarily represent the abundance of fungi, they provide reliable information concerning forest diversity without excessive effort and cost (Tóth \& Barta 2010). Each macrofungal taxon was attributed to the most likely trophic group, according to Arnolds et al. (1995) and to personal field observations. Three data sets were then obtained for the plants (presence-absence of all vascular plants, presence-absence and frequency of woody plants) and ten data sets were obtained from the carpophores of fungi (presence- absence and frequency of the following trophic groups: (i) EMF, ectomycorrhizal fungi; (ii) Sh, humicolous saprotrophs; (iii) Sl, litter saprotrophs; (iv) Sw, lignicolous saprotrophs; and (v) P, parasites. Coprophilous saprotrophs were absent. The above approach was adopted because many macrofungi are related to woody plant species by their trophic requirements and trophic groups may be strongly shaped by forest composition and structure (e.g., mycorrhizal species and many saprotrophic fungi - Roberts et al. 2004, De Bellis et al. 2006, Santos-Silva et al. 2011).

Sampling of plant species was carried out in June and July 2010, when leaves were fully extended. Sampling of macrofungi was conducted from April 2009 to November 2011, with a higher frequency (up to once a month) from September to December, when conditions were generally optimal for fungal fruiting. Nomenclature of plant species was given according to Conti et al. (2005). Fungal species nomenclature was based on the CABI Bioscience Database of Fungal Names (http://www.indexfungorum.org/Names/nam es.asp).

\section{Statistical analysis}

Data collected from the two study sites were pooled, since all plots shared similar features as for forest structure, environmental characteristics and history over the last 40 years. Only the EMF (ectomycorrhizal fungi), Sh (humicolous saprotrophs) and Sw (lignicolous saprotrophs) datasets could be used in the analysis, as Sl (litter saprotrophs) and $\mathrm{P}$ (parasites) were only present in a few plots. Accordingly, the analysis was carried out using three plant data sets and six fungal data sets (18 combinations), following two main steps. In the first step, a hierarchical cluster analysis using the Bray-Curtis dissimilarity index $(1-$ Sørensen's index $)$ and flexible beta $(\beta=-0.25)$ was applied on the three plant species data sets following the recommendations of McCune \& Grace (2002), and three classifications were obtained based on: (1) presence/absence of all plants; (2) presence/absence of woody species; and (3) frequency of woody species.

In the second step, Multiple Response Permutation Procedures (MRPP) were used to test the performance of each classification applied to the fungi data sets. Cluster groups were subjected to a set of cross-tests on the macrofungi data sets and a cross-test was only accepted when significant $(\mathrm{p}<0.05)$. Moreover, MRPP for a posteriori classification (self-test) was applied to obtain the "best possible" values of such statistics, for numerical comparison with the values of the a priori classification (cross-test). MRPP is a data-dependent permutation test that compares dissimilarities within and among groups, but does not require any assump- 
Tab. 1 - Results of the cross-test based on Multiple Response Permutation Procedures (MRPP) carried out on classifications of plants ap plied to trophic groups of fungi. Clusters are reported in columns and fungal groups are displayed in rows. P-values are reported for significant cross-tests only. Self-tests performed with a posteriori classification to compare $A$ and $T$ values obtained by MRPP are also shown. (n.s.): not significant.

\begin{tabular}{|c|c|c|c|c|c|c|c|c|c|c|}
\hline \multirow{3}{*}{ Data Type } & \multirow{3}{*}{ Fungi } & \multicolumn{6}{|c|}{ Woody plants } & \multirow{2}{*}{\multicolumn{3}{|c|}{$\begin{array}{c}\text { All plants } \\
\text { Presence-absence data }\end{array}$}} \\
\hline & & \multicolumn{3}{|c|}{ Presence-absence data } & \multicolumn{3}{|c|}{ Frequency data } & & & \\
\hline & & $A$ & $T$ & $\mathbf{p}$ & $A$ & $T$ & $\mathbf{p}$ & $A$ & $T$ & $\mathbf{p}$ \\
\hline Self test & - & 0.151 & -8.972 & - & 0.261 & -14.236 & - & 0.092 & -8.947 & - \\
\hline \multirow{3}{*}{$\begin{array}{l}\text { Presence-absence } \\
\text { data }\end{array}$} & EMF - Ectomycorrhizal & 0.020 & -2.420 & 0.016 & 0.018 & -2.164 & n.s. & 0.014 & -1.684 & n.s. \\
\hline & Sw - Lignicolous saprotrophs & -0.006 & 0.599 & n.s. & -0.008 & 0.850 & & -0.006 & 0.583 & n.s. \\
\hline & Sh - Humicolous saprotrophs & -0.004 & 0.419 & n.s. & -0.014 & -1.434 & n.s. & -0.003 & 0.273 & n.s. \\
\hline \multirow{3}{*}{ Frequency data } & EMF - Ectomycorrhizal & 0.019 & -3.149 & 0.005 & 0.013 & -2.274 & 0.021 & 0.014 & -1.929 & 0.038 \\
\hline & Sw - Lignicolous saprotrophs & 0.008 & -1.036 & n.s. & -0.014 & 1.496 & n.s. & 0.002 & -0.210 & n.s. \\
\hline & Sh - Humicolous saprotrophs & 0.005 & -0.621 & n.s. & 0.017 & -2.166 & 0.037 & 0.011 & -1.446 & n.s. \\
\hline
\end{tabular}

tions of multivariate normality and homogeneity of variance to test the hypothesis of no differences among groups of sampling units assessed through a Monte Carlo permutation procedure (Zimmerman et al. 1985, Biondini et al. 1988). This consists of the $A$ statistics, which estimates the within-group homogeneity (higher values indicate a high degree of homogeneity), and the $T$ statistics, which measures the among-group separability (large negative value of $T$ indicates a high separability of groups). When $A=0$, the within-group community heterogeneity equals that expected by chance, while if $A<0$ the heterogeneity exceeds that expected by chance. The MRPP analysis was performed using the software package PCORD (McCune \& Mefford 2011).

Ordination analysis, formerly applied to investigate the congruence among taxonomic groups, including fungal species (Sætersdal et al. 2003, Similä et al. 2006, Santi et al. 2010), was used to evaluate the congruence of species composition between the plant and the macrofungal data sets considered. To investigate the main gradients in the species data for the two taxonomic groups, Detrended Correspondence Analysis (DCA) was applied for each group (Hill \& Gauch 1980), including down-weighting of rare species. Principal Component Analysis (PCA), was then used to analyse the congruence of the data sets because of: (i) the relatively short length of the compositional gradients; and (ii) their potential use with empty samples, contrary to unimodal methods (Leps \& Smi- lauer 2003). Ordination analysis was performed using the CANOCO v. 4.5 software package (ter Braak \& Šmilauer 2002). The potential use of the compositional patterns of vascular plant data sets as surrogates for those of different macrofungal data sets was tested by Spearman's rank correlation of the sample scores along the first PCA axis (a total of nine PCAs were extracted). Significant (positive or negative) correlation indicates a concurrent variation in the species composition among taxonomic groups. Furthermore, Spearman's correlation coefficient was used to assess the association between plant and fungi species usng the data sets for which significant concordance was found.

\section{Results}

\section{Plant community composition}

A total of 108 plant species were found, including 18 species of trees and shrubs taller than $2 \mathrm{~m}$ (woody plants). The mean number of species per plot was $27 \pm 8$ (SD) and that of woody plants was $4.3 \pm 1.7$. Concerning trees, Quercus cerris was dominant in all plots, with a higher mean number of individuals $\left(11.2 / 100 \mathrm{~m}^{2}\right)$ than other tree species (such as Fraxinus ornus, Quercus pubescens and Ulmus minor). Tall shrubs (such as Cornus mas, Crataegus monogyna, Juniperus communis and Prunus spinosa) and vines (Hedera helix and Tamus communis) were also frequent. The most common herbaceous plants were perennials with underground tissues (rhizomes and bulbs), such as Brachy- podium sylvaticum, B. rupestre, Viola alba and Melica uniflora.

\section{Fungal community composition}

A total of 333 macrofungal species were found in the study plots. The three most representative trophic groups were: ectomycorrhizal fungi (EMF) with 157 species and a mean number per plot of $20.6 \pm 7.7(\mathrm{SD})$; humicolous saprotrophs ( $\mathrm{Sh}$ ) with 81 species and a mean number per plot of $8.3 \pm 3.4$; and lignicolous saprotrophs $(\mathrm{Sw})$ with 78 species, whose mean number per plot was 11.0 \pm 4.4. Mycena vitilis (Sw) was the most common species (present in $93 \%$ of plots), followed by Cortinarius rigens (EMF), Entoloma rhodopolium and Rhodocollybia butyracea (Sh). Litter saprotrophs (Sl), with 10 species, and parasites $(\mathrm{P})$, with 7 species, had the lowest mean number of carpophores (1.8 and 0.9 , respectively) and were not detected in many plots.

\section{Community concordance between plants and fungi}

The three classifications identified by clusters analysis (see "Materials and Methods") were cut to hierarchical levels (nodes) corresponding to three distinct groups, each containing at least 2 plots (from 5 to 19 plots for each group). Among the cut levels of classifications the percentage of information left had quite similar values (from 10 to $20 \%$ ).

The cross-test concordance analysis carried out revealed five significant results out of eighteen combinations (Tab. 1), and all the

Tab. 2 - Spearman's rank correlation coefficients $(\rho)$ between the sample scores on the first PCA axis performed on plant (columns) and fungi (rows) data sets. The variance accounted for by the first axis of each PCA is shown in brackets. $(* *): p<0.01 ;(*)$ : $p<0.05$.

\begin{tabular}{|c|c|c|c|c|c|}
\hline \multirow{3}{*}{ Data set } & \multirow{3}{*}{ Fungi Trophic Group } & \multirow{3}{*}{$\begin{array}{c}\text { Variance } \\
(\%)\end{array}$} & \multicolumn{2}{|c|}{ Woody plants } & \multirow{3}{*}{$\begin{array}{c}\text { All plants } \\
\text { Presence data } \\
(47.4)\end{array}$} \\
\hline & & & Presence data & Frequency data & \\
\hline & & & $(60.2)$ & (78.9) & \\
\hline \multirow[t]{3}{*}{ Presence-absence data } & EMF - Ectomycorrhizal & $(31.9)$ & -0.14 & $0.47 * *$ & -0.32 \\
\hline & Sw - Lignicolous saprotrophs & $(36.2)$ & -0.06 & -0.02 & -0.05 \\
\hline & Sh - Humicolous saprotrophs & $(30.9)$ & -0.07 & $0.38 *$ & -0.26 \\
\hline \multirow[t]{3}{*}{ Frequency data } & EMF - Ectomycorrhizal & $(25.1)$ & -0.14 & 0.23 & -0.31 \\
\hline & Sw - Lignicolous saprotrophs & $(30.8)$ & 0.04 & -0.08 & 0.09 \\
\hline & Sh - Humicolous saprotrophs & $(51.4)$ & 0.14 & $-0.45^{*}$ & 0.05 \\
\hline
\end{tabular}


three classifications gave the best results when applied to the fungal data set based on frequency (number of fruiting bodies per species - see MRPP statistics and significance). All the three classifications showed significant concordance when applied to mycorrhizal fungi. Considering each classifications individually, that of woody plants ba- sed on frequency data also gave significant results when applied to the frequency of humicolous fungi. On the other hand, the classifications based on fungal presence-absence data gave poor results (woody plant presence/absence data applied to mycorrhizal fungi). Lignicolous fungi gave no significant results.
The correlations between the sample scores on the first PCA axis for the different groups were weak and mostly not statistically significant (Tab. 2). The two groups, plants and fungi, did not follow comparable compositional gradients (presence-absence data) as revealed by rather different positions of the plots in the PCA scatter-plots (not shown).

Tab. 3 - Spearman's rank correlation coefficients $(\rho)$ between woody plants and ectomycorrhizal fungi (EMF), based on frequency data. The symbol (+) indicates $\rho>0.50$ and $p$-value $<0.01$.

\begin{tabular}{|c|c|c|c|c|c|c|c|c|c|c|c|c|c|c|c|c|c|}
\hline Species & 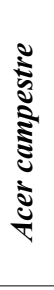 & 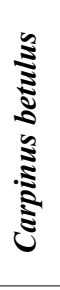 & 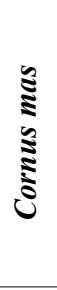 & 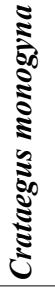 & 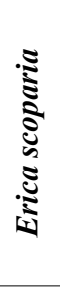 & 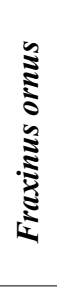 & 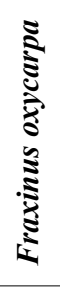 & 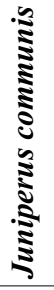 & 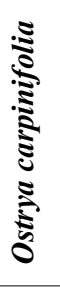 & 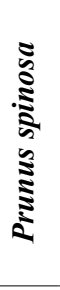 & 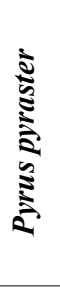 & 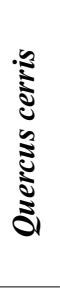 & 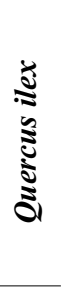 & 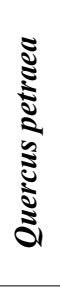 & 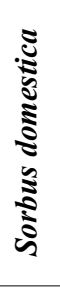 & 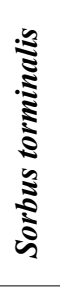 & 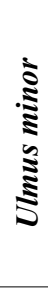 \\
\hline Amanita pantherina & - & - & - & - & - & + & - & - & - & - & - & - & - & - & + & - & - \\
\hline Amanita phalloides & - & - & - & - & - & - & - & - & - & - & - & - & + & - & - & - & - \\
\hline Boletus fechtneri & - & - & - & - & - & - & - & - & - & - & - & - & - & - & + & - & - \\
\hline Cortinarius argutus & - & - & - & - & - & - & - & - & + & - & - & - & - & - & - & - & - \\
\hline Cortinarius betuletorum & - & - & - & - & - & - & - & - & - & - & - & - & - & - & + & - & - \\
\hline Cortinarius bolaris & - & - & - & - & - & - & - & - & - & + & - & - & - & - & - & - & - \\
\hline Cortinarius casimiri & - & - & - & - & - & - & + & - & - & - & - & - & - & + & - & - & - \\
\hline Cortinarius decipiens & - & - & - & - & - & - & - & - & + & - & - & - & - & - & - & - & - \\
\hline Cortinarius dionysae & - & - & - & - & - & - & - & - & - & + & - & - & - & - & - & - & - \\
\hline Cortinarius rufo-olivaceus & - & - & - & - & - & - & - & - & - & - & - & - & - & - & + & - & - \\
\hline Cortinarius trivialis & - & - & - & - & - & - & - & - & - & - & - & - & - & - & + & - & - \\
\hline Craterellus cornucopioides & - & - & - & - & - & - & - & - & - & - & - & - & + & - & - & - & - \\
\hline Genea fragrans & - & - & - & - & - & - & - & - & - & + & - & - & - & - & - & - & - \\
\hline Hebeloma gigaspermum & - & - & + & - & - & - & - & - & - & - & - & - & - & - & - & - & - \\
\hline Hebeloma sinapizans & - & - & - & - & - & - & - & - & - & - & - & + & - & - & - & - & - \\
\hline Hygrophorus arbustivus & - & - & - & - & - & - & - & + & - & - & - & - & - & - & - & - & - \\
\hline Hygrophorus roseodiscoideus & - & - & - & - & - & + & - & - & - & - & - & - & + & - & - & - & - \\
\hline Inocybe cincinnata & - & - & - & + & - & - & - & - & - & - & - & - & - & - & - & - & - \\
\hline Inocybe flavella & - & - & - & + & - & - & - & - & - & - & - & - & - & - & - & - & - \\
\hline Inocybe glabripes & - & - & - & - & - & - & - & - & - & - & - & - & + & - & - & - & - \\
\hline Inocybe godeyi & - & - & - & - & - & - & - & - & - & + & - & - & - & - & - & - & - \\
\hline Inocybe oblectabilis & - & - & - & - & - & - & - & - & + & - & - & - & - & - & - & - & - \\
\hline Inocybe obscurobadia & - & - & - & - & - & - & - & - & - & + & - & - & - & - & - & - & - \\
\hline Inocybe praetervisa & - & - & - & - & - & - & - & - & - & - & + & - & - & - & - & - & - \\
\hline Lactarius acerrimus & + & - & - & - & - & - & - & - & - & - & - & - & - & - & - & - & - \\
\hline Lactarius camphoratus & - & + & - & - & - & - & - & - & - & - & - & - & - & - & - & - & - \\
\hline Lactarius scrobiculatus & - & - & - & - & + & - & - & - & - & - & - & - & - & - & + & - & - \\
\hline Leccinellum crocipodium & - & - & - & - & - & - & - & - & - & - & - & - & - & - & + & - & - \\
\hline Otidea alutacea & - & - & - & - & - & - & - & - & - & - & - & - & - & - & + & - & - \\
\hline Russula atropurpurea & - & - & - & - & - & - & - & - & - & - & - & - & - & - & + & - & - \\
\hline Russula aurea & - & - & - & - & - & - & - & - & - & - & - & - & - & - & + & - & - \\
\hline Russula chloroides & - & + & - & - & - & - & - & - & - & - & - & - & - & - & - & - & - \\
\hline Russula curtipes & - & - & - & - & - & - & - & - & - & - & - & - & - & - & - & + & - \\
\hline Russula cyanoxantha & - & - & - & - & - & - & - & - & - & - & - & - & + & - & - & - & - \\
\hline Russula delica & - & + & - & - & - & - & - & - & + & - & - & - & - & - & - & - & - \\
\hline Russula grata & - & + & - & - & - & - & - & - & - & - & - & - & - & - & - & - & - \\
\hline Russula maculata & - & - & - & - & - & + & - & - & - & - & - & - & - & - & - & - & - \\
\hline Russula pectinatoides & - & - & - & - & + & - & - & - & - & - & - & - & - & - & + & - & - \\
\hline Russula pseudointegra & - & - & - & - & - & - & - & - & - & + & - & - & - & - & - & - & - \\
\hline Russula rubra & - & + & - & - & - & - & - & - & + & - & - & - & - & - & - & - & - \\
\hline Russula rutila & - & - & - & - & - & - & - & - & - & - & - & - & - & - & - & - & + \\
\hline Thelephora anthocephala & - & - & - & - & - & - & - & - & - & + & - & - & - & - & - & - & - \\
\hline Tricholoma columbetta & - & - & - & - & - & - & - & - & - & - & - & - & - & - & - & + & - \\
\hline Tricholoma orirubens & - & - & - & - & - & - & - & - & - & + & - & - & - & - & - & - & - \\
\hline Tricholoma ustaloides & - & - & - & - & - & + & - & - & - & - & - & - & - & - & - & - & - \\
\hline Tuber excavatum & - & - & - & - & - & - & - & + & - & - & - & - & - & - & - & - & - \\
\hline
\end{tabular}


Tab. 4 - Spearman's rank correlation coefficients $(\rho)$ between woody plants and humicolous saprotrophs (Sh), based on frequency data. The symbol $(+)$ indicates $\rho>0.50$ and $p$-value $<0.01$.

\begin{tabular}{|c|c|c|c|c|c|c|c|c|c|c|c|c|c|}
\hline Species & 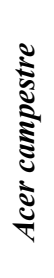 & 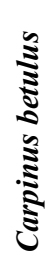 & 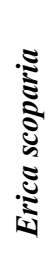 & 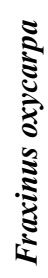 & 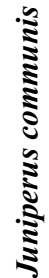 & 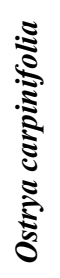 & 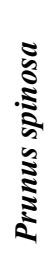 & 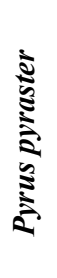 & 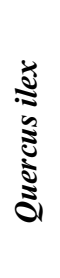 & 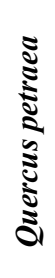 & 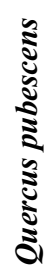 & 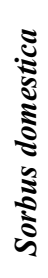 & 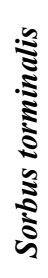 \\
\hline Agaricus fuscofibrillosus & - & - & - & - & - & - & - & - & - & - & - & + & - \\
\hline Clathrus ruber & - & - & - & - & + & - & + & - & - & - & - & - & - \\
\hline Clavariadelphus pistillaris & - & - & - & + & - & - & - & - & - & + & - & - & - \\
\hline Entoloma hirtipes & - & - & + & - & - & - & - & - & - & - & - & - & - \\
\hline Entoloma rhodopolium & - & - & - & - & - & - & - & - & - & - & + & - & - \\
\hline Galerina graminea & - & - & - & - & - & - & - & - & - & - & - & + & - \\
\hline Gymnopus dryophilus & - & - & - & - & - & - & - & + & - & - & - & - & - \\
\hline Hygrocybe ceracea & - & + & - & - & - & - & - & - & - & - & - & - & - \\
\hline Hygrocybe conica & - & - & - & - & - & - & - & - & + & - & - & - & - \\
\hline Lepiota lilacea & - & + & - & - & - & + & - & - & - & - & - & - & - \\
\hline Lepiota subincarnata & - & - & - & - & - & - & - & - & - & - & - & - & + \\
\hline Macrolepiota procera & - & - & - & - & - & - & - & - & - & - & - & + & - \\
\hline Macrotyphula juncea & - & - & - & - & - & - & - & - & - & - & - & + & - \\
\hline Mycena epipterygia & - & - & - & + & - & - & - & - & - & + & - & - & - \\
\hline Mycetinis alliaceus & - & - & - & - & - & - & - & + & - & - & - & - & - \\
\hline Pluteus ephebeus & - & - & - & - & - & - & - & - & - & - & - & + & - \\
\hline Psathyrella obtusata & + & - & - & - & - & - & - & - & - & - & - & - & - \\
\hline Psathyrella tephrophylla & + & - & - & - & - & + & - & - & - & - & - & - & - \\
\hline Scutellinia armatospora & - & - & - & - & - & + & - & - & - & - & - & - & - \\
\hline
\end{tabular}

The correlations between woody plants (frequency data) and EMF (presence/absence data) and Sh (presence/absence and frequency data) fungi were significant.

\section{Associations between plants and mycorrhizal fungi}

Results of the correlation analysis between woody and fungi species (EMF and Sh) based on frequency data are reported in Tab. 3 and Tab. 4. Overall, a significant positive association was detected between $46 \mathrm{EMF}$ and 17 woody plants, including tree and shrub species (Tab. 3). Sorbus domestica and Prunus spinosa were correlated with a greater number of EMF (11 and 8 correlations, respectively) than any other plants. The genus Russula includes the largest number of EMF species correlated with woody plants; all species of the genus Russula found in this study were included in Tab. 3. Concerning Sh fungi, significant positive association were found between 19 Sh fungi and 13 woody plants (Tab. 4). Tree species as Fraxinus oxycarpa and Quercus petraea were associated exclusively to the same assembly of EMF (Cortinarius casimiri and Hygrophorus roseodiscoideus) and Sh fungi (Clavariadelphus pistillaris and Mycena epipterygia).

\section{Discussion}

The high number of fungal species found in this investigation confirmed the evidence previously reported by Salerni et al. (2001) that broadleaved deciduous forests dominated by Quercus cerris support a high fungal richness.

According to observations from previous studies (Paavola et al. 2003, Landi et al. 2012), each plant data set gave a better value of MRPP statistics under a posteriori classification (self-test) than under a priori classification (cross-test).

Considering the a priori classification, better results were obtained in the MRPP analysis when the classification based only on woody species was used, in comparison with the classification obtained including both herbaceous and woody species. Such result may be interpreted as due to the fact that herbaceous species are not functionally relevant to EMF species, therefore their inclusion in the analysis provides a lower variance accounted for in the data sets analyzed. The concordance between the woody species community with the EMF community found in this investigation agrees with previous studies demonstrating that the EMF community composition is mainly related to tree and shrub species (Kernaghan et al. 2003, Cripps 2004, Lodge et al. 2004, De Bellis et al. 2006, Kirk et al. 2008). A similar concordance was also found between the woody species and the Sh fungi communities, but only when both data sets were based on frequency. Analogously, this may be interpreted as an effect of the chemical composition of the litter that varies among different plant communities (Berg \& McClaugherty 2007), thus affecting the composition of the Sh fungal community. Moreover, it is possible that the species classified as Sh have expanded their trophism (Whitfield 2007).

The ordination analysis applied in this study revealed that the scores on the ordination axes for woody species were significantly correlated with those obtained for EMF and Sh species, clearly indicating a spatial covariation of EMF and Sh fungal groups and woody species along the same environmental gradients.

Concerning the association between communities of woody plants and fungi, it is well known that many EMF show a degree of host specificity (Molina et al. 1992, Tyler 1992, Whitfield 2007). Moreover, multivariate statistics have shown that macrofungal communities can be clearly defined and delineated from the abundance patterns of their host tree species in temperate forests (Humphrey et al. 2000, Ferris et al. 2000, Buée et al. 2011, O'Hanlon \& Harrington 2012). In this study, EMF were associated with woody plants, including not only trees but also aged shrubs (taller than $2 \mathrm{~m}$ ).

In Italy, the intensive exploitation occurred in the past has deeply modified the forest composition and structure, affecting in particular the understorey layer that was removed to ensure optimal growing conditions to trees. On the other hand, the results of this study suggest that the presence of old shrubs in the understorey have an overriding influence on EMF communities in broadleaf de- 
ciduous forests dominated by Quercus cerris. Indeed, it may be hypothesized that the presence of a shrub understorey can be used as an "ecological indicator" for EMF, which seem to prefer mature forests (e.g., genus Russula - Mason et al. 1982, Dighton et al. 1986, Deacon \& Fleming 1992).

Our data indicates that many EMF exhibit preferences for one or two hosts. However, some woody plants, such as Sorbus domestica and Prunus spinosa, appear to be associated with many EMF. To our knowledge, these species are not thought to host symbiotic fungi, though it has been hypothesized that they play an important role during the fruiting process of some fungal species (Chevalier et al. 1978, Bencivenga et al. 1990). McDonald et al. (2010) identified ectomycorrhizal species of the genera Cortinarius, Inocybe and Tricholoma that form epigeous fruiting bodies with a species of Rosaceae. On the other hand, compared to other higher taxa of the northern hemisphere (e.g., Pinaceae and Fagales), only a few studies have investigated the ectomycorrhizal fungi on Rosaceae (Dickie \& Moyersoen 2008).

Our results also showed that the co-occurrence of Fraxinus oxycarpa and Quercus petraea, both associated with peculiar ecological conditions (Temunović et al. 2012, Sanders et al. 2014) seems to promote distinct assemblages of EMF and Sh fungi, as compared with other woody species. As a consequence, strategies for the conservation of fungi should aim at retaining diverse assemblages of host species and different structures across forests.

In this study, few Sh fungal species were significantly associated with woody plants. This may be due to the fact that Sh species are more dependent on the whole community (and its soil niches) than to individual trees In any case, abiotic factors (e.g., soil nutrients and microclimate - Twieg et al. 2009 Santos-Silva et al. 2011) may also play an important role in the distribution of such fungal trophic groups, and then the host specificity of macrofungi observed on a local scale can be different at a regional scale.

\section{Conclusions}

The results of our investigation support the evidence of woody plant communities as a useful indicator of the community of EMF. As a consequence of fungal host preferences, characteristic assemblages of EMF can be found in association with different tree and shrub species combinations.

Intensive silvicultural practices may dramatically change the composition and structure of woody species, affecting therefore their potential for colonization by host-specific symbionts. Consequently, strategies for the conservation of fungi should aim at increasing the biodiversity of host species and retaining different structures in broadleaf deciduous forests of the Mediterranean area.

To test the general applicability of the relationships found in this study, and to predict the fungal communities based on the woody species communities in Mediterranean deciduous forests, further investigations are needed including more replications over a broader range of sites.

\section{Acknowledgements}

This work was partly supported by a Management Project of the Italian Forest Service (Corpo Forestale dello Stato). We thank all our colleagues who participated in the sampling efforts, particularly Pamela Leonardi, Flavio Frignani, Martino Danielli and Lorenzo Pecoraro, also for their precious help with plant and fungal determination, and Emma Thorley for language editing.

\section{References}

Arnolds E (1981). Ecology and coenology of macrofungi in grasslands and moist heathlands in Drenthe, the Netherlands. Part 1. Introduction and Synecology. Bibliotheca Mycologica 83: 1410.

Arnolds E, Kuyper TW, Noordeloos ME (1995). Overzicht van de paddestoelen in Nederland [Overview of mushrooms in Netherlands]. Nederlandse Mycologische Vereniging, Wijster, The Netherlands, pp. 872. [in Dutch]

Balmford A, Jayasuriya AH, Green MJB (1996). Using higher-taxon richness as a surrogate for species richness. 2. Local applications. Proceedings of the Royal Society B 263: 1571-1575. doi: 10.1098/rspb.1996.0230

Bencivenga M, Calandra R, Giovanotti E, Russi L (1990). Aspetti pedologici e vegetazionali delle tartufaie di alcune specie di "tartufi minori" [Soil and vegetation aspects of truffle grounds for some species of "minor truffles"]. Annali della Facoltà di Agraria 50: 7-45. [in Italian]

Berg B, McClaugherty C (2007). Plant litter: decomposition, humus formation, carbon sequestration $\left(2^{\text {nd }}\right.$ edn). Springer-Verlag, Heidelberg, Berlin, Germany, pp. 338

Berglund H, Jonsson BG (2001). Predictability of plant and fungal species richness of old-growth boreal forest islands. Journal of Vegetation Science 12: 857-866. - doi: 10.2307/3236874

Biondini ME, Mielke PW, Berry KJ (1988). Datadependent permutation techniques for the analysis of ecological data. Vegetatio 75: 161-168. [online] URL: http://link.springer.com/article/ 10.1007/BF00045630

Brussaard L, Kuyper TW, De Goede RGM (2001). On the relationships between nematodes, mycorrhizal fungi and plants: functional composition of species and plant performance. Plant and Soil 232: 155-165. - doi: 10.1023/A:1010398322637 Buée M, Maurice JP, Zeller B, Andrianarisoa S, Ranger J, Courtecuisse R, Marçais B, Le Tacon F (2011). Influence of tree species on richness and diversity of epigeous fungal communities in a French temperate forest stand. Fungal Ecology
4: 22-31. - doi: 10.1016/j.funeco.2010.07.003 Chevalier G, Desmas C, Frochot H, Riousset L (1978). L'espèce Tuber aestivum Vitt. II. Ecologie [The species Tuber aestivum Vitt. II. Ecology]. Mushroom Science 10 (1): 977-993. [in French]

Chiarucci A, D'Auria F, De Dominicis V, Laganà A, Perini C, Salerni E (2005). Using vascular plants as a surrogate taxon to maximize fungal species richness in reserve design. Conservation Biology 19: 1644-1652. - doi: 10.1111/j.15231739.2005.00202.x

Conti F, Abbate G, Alessandrini A, Blasi C (2005). An annotated checklist of the Italian vascular flora. Palombi Editore, Rome, Italy, pp. 420.

Cripps CL (2004). Fungi in forest ecosystems: systematics, diversity and ecology. The New York Botanical Garden, New York, USA, pp. 363.

Deacon JW, Fleming LV (1992). Interactions of ectomycorrhizal fungi. In: "Mycorrhizal Functioning, an Integrative Plant-Fungal Process" (Allen MF ed). Chapman and Hall, New York, USA, pp. 249-300.

De Bellis T, Kernaghan G, Bradley R, Widden P (2006). Relationships between stand composition and ectomycorrhizal community structure in boreal mixed-wood forests. Microbial Ecology 52: 114-126. - doi: 10.1007/s00248-006-9038-8 Dickie IA, Moyersoen B (2008). Towards a global view of ectomycorrhizal ecology. New Phytologist 180: 263-265. - doi: 10.1111/j.1469-8137. 2008.02635.x

Dighton J, Poskitt JM, Howard DM (1986). Changes in occurrence of basidiomycete fruit bodies during forest stand development with specific reference to mycorrhizal species. Transactions of the British Mycological Society 87: 163 171. - doi: 10.1016/S0007-1536(86)80017-1

Ferris R, Peace AJ, Newton AC (2000). Macrofungal communities of lowland Scots pine ( $\mathrm{Pi}$ nus sylvestris L.) and Norway spruce (Picea abies (L.) Karsten.) plantations in England: relationships with site factors and stand structure. Forest Ecology and Management 131: 255-267. doi: 10.1016/S0378-1127(99)00218-2

Gaston KJ (2000). Global patterns in biodiversity. Nature 405: 220-227. - doi: 10.1038/35012228

Hawksworth DL (1991). The fungal dimension of biodiversity: magnitude, significance and conservation. Mycological Research 95: 641-655. - doi: 10.1016/S0953-7562(09)80810-1

Hawksworth DL (2001). The magnitude of fungal diversity: the 1.5 million species estimate revised. Mycological Research 105: 1422-1432. doi: $10.1017 / \mathrm{S} 0953756201004725$

Heino J, Mykrä H (2006). Assessing physical surrogates for biodiversity: do tributary and stream type classifications reflect macroinvertebrate assemblage diversity in running waters? Biological Conservation 129: 418-426. - doi: 10.1016/j.biocon.2005.11.009

Hill MO, Gauch HG (1980). Detrended correspondence analysis, an improved ordination technique. Vegetatio 42: 47-58. - doi: 10.1007/BF0004 
8870

Humphrey JW, Newton AC, Peace AJ, Holden E (2000). The importance of conifer plantations in northern Britain as a habitat for native fungi. Biological Conservation 96: 241-252. - doi: 10.1016/S0006-3207(00)00077-X

Kernaghan G, Widden P, Bergeron Y, Légaré S, Paré D (2003). Biotic and abiotic factors affecting ectomycorrhizal diversity in boreal mixedwoods. Oikos 102: 497-504. - doi: 10.1034/ j.1600-0706.2003.12415.x

Kirk P, Cannon PF, Minter DW, Stalpers JA (2008). Ainsworth \& Bisby's Dictionary of the Fungi $\left(10^{\text {th }} \mathrm{edn}\right)$. CAB International, Wallingford, UK, pp. 771.

Landi M, Piazzini S, Nucci A, Saveri C, Angiolini C (2012). Can macrophytes be a surrogate for amphibians and physico-chemical features in pond classifications? Aquatic Botany 101: 1-7. doi: 10.1016/j.aquabot.2012.03.003

Leps J, Smilauer P (2003). Multivariate analysis of ecological data using CANOCO. Cambridge University Press, Cambridge, UK, pp. 282.

Lodge DJ, Ammirati JF, O’Dell TE, Mueller GM (2004). Collecting and describing Macrofungi. In: "Biodiversity of Fungi, Inventory and Monitoring Methods" (Müller GM, Bills GF, Foster MS eds). Elsevier Academic Press, Oxford, UK, pp. 129-158.

Magurran AE (2004). Measuring biological diversity. Blackwell Publishing company, Oxford, UK, pp. 256.

Mason PA, Last FT, Pelham J, Ingleby K (1982). Ecology of some fungi associated with an ageing stand of birches (Betula pendula and Betula pubescens). Forest Ecology and Management 4: 19-39. - doi: 10.1016/0378-1127(82)90026-3

McCune B, Grace JB (2002). Analysis of ecological communities. MJM Software Design, Gleneden Beach, OR, USA, pp. 300.

McCune B, Mefford MJ (2011). PC-ORD: multivariate analysis of ecological data (v. 6.0). MJM Software Design, Gleneden Beach, OR, USA, pp. 28.

McDonald KR, Pennell J, Frank JL, Southworth D (2010). Ectomycorrhizas of Cercocarpus ledifolius (Rosaceae). American Journal of Botany 97: 1867-1872. - doi: 10.3732/ajb.0900357

McMullan-Fisher SJM, Kirkpatrick JB, May TW, Pharo EJ (2009). Surrogates for macrofungi and mosses in reservation planning. Conservation Biology 24: 730-736. - doi: 10.1111/j.1523-17 39.2009.01378.x

Molina RJ, Massicotte H, Trappe JM (1992). Specificity phenomena in mycorrhizal symbioses: community-ecological consequences and practical implications. In: "Mycorrhizal Functioning, an Integrative Plant-fungal Process" (Allen MF ed). Chapman and Hall, New York, USA, pp. 357-423.

Mortiz C, Richardson KS, Ferrier S, Monteith GB, Stanisic J, Williams S, Whiffin T (2001). Biogeographical concordance and efficiency of taxon indicators for establishing conservation priority in a tropical rainforest biota. Proceedings of the Royal Society B 268: 1875-1881. - doi: 10.1098/rspb.2001.1713

Murphy DD, Weiland PS, Cummins KW (2011). A critical assessment of the use of surrogate species in conservation planning in the Sacramento-San Joaquin Delta, California (USA). Conservation Biology 25: 873-878. - doi: 10.1111/j.1523-1739.2011.01711.x

O'Hanlon R, Harrington TJ (2012). Macrofungal diversity and ecology in four Irish forest types. Fungal Ecology 5: 499-508. - doi: 10.1016/j.funeco.2011.12.008

Onofri S, Bernicchia A, Filipello Marchisio V, Padovan F, Perini C, Ripa C, Salerni E, Savino E, Venturella G, Vizzini A, Zotti M, Zucconi L (2005). Checklist dei funghi italiani Basidiomycetes [Checklist of Italian fungi Basidiomycota]. Carlo Delfino Editore, Sassari, Italy, pp. 380.

Öster M (2008). Low congruence between the diversity of Waxcap (Hygrocybe spp.) fungi and vascular plants in semi-natural grasslands. Basic and Applied Ecology 9: 514-522. - doi: 10.1016/ j.baae.2007.11.006

Paavola R, Muotka T, Virtanen R, Heino J, Kreivi $P$ (2003). Are biological classifications of headwater streams concordant across multiple taxonomic groups? Freshwater Biology 48: 19121923. - doi: 10.1046/j.1365-2427.2003.01131.x Packham JM, May TW, Brown MJ, Wardlaw TJ, Mills AK (2002). Macrofungal diversity and community ecology in mature and regrowth wet eucalypt forest in Tasmania: a multivariate study. Austral Ecology 27: 148-161. - doi: 10.1046/ j.1442-9993.2002.01167.x

Paszkowski CA, Tonn WA (2000). Community concordance between the fish and aquatic birds of lakes in northern Alberta, Canada: the relative importance of environmental and biotic factors. Freshwater Biology 43: 421-437. - doi: 10.1046/ j.1365-2427.2000.00512.x

Pharo EJ, Beattie AJ, Binns D (1999). Vascular plant diversity as a surrogate for bryophyte and lichen diversity. Conservation Biology 13: 282292. - doi: 10.1046/j.1523-1739.1999.013002 282.x

Qian H, Ricklefs RE (2008). Global concordance in diversity patterns of vascular plants and terrestrial vertebrates. Ecology Letters 11: 547-553. doi: 10.1111/j.1461-0248.2008.01168.x

Roberts C, Ceska O, Kroeger P, Kendrick B (2004). Macrofungi from six habitats over five years in Clayoquot Sound, Vancouver Island. Canadian Journal of Botany 82: 1518-1538. doi: $10.1139 / \mathrm{b} 04-114$

Ryti RT (1992). Effect of the focal taxon on the selection the nature reserves. Ecological Applications 2: 404-410. - doi: 10.2307/1941875

Sætersdal M, Gjerde I, Blom HH, Ihlen PG, Myrseth EW, Pommeresche R, Skartveit J, Solhøy T, Aas O (2003). Vascular plants as a surrogate species group in complementary site selection for bryophytes, macrolichens, spiders, carabids, staphylinids, snails, and wood living polypore fungi in a northern forest. Biological Conservation 115: 21-31. - doi: 10.1016/S00063207(03)00090-9
Salerni E, Laganà A, De Dominicis V (2001). Mycocoenological studies in deciduous oak woods of central-southern Tuscany (Italy). Cryptogamie Mycologie 22: 35-55. - doi: 10.1016/S01811584(01)01054-5

Salerni E, Perini C (2007). Mycodiversity of nature reserves in central Italy. Acta Mycologica 42: 5-19. - doi: 10.5586/am.2007.001

Salerni E, Baglioni F, Mazzei T, Gardin L, Ciabatti F, Leonardi P, Vesprini J, Perini C (2010). Efectos de las diversas técnicas culturales sobre la producción de Tuber aestivum Vitt. y de Tuber melanosporum Vitt. en dos plantaciones experimentales en Italia central [Effects of different cultural techniques on the production of Tuber aestivum Vitt. and Tuber melanosporum Vitt. in two experimental plantations in central Italy]. ZIZAK 7: 47-62. [in Spanish]

Sanders TGM, Pitman R, Broadmeadow MSJ (2014). Species-specific climate response of oaks (Quercus spp.) under identical environmental conditions. iForest 7: 61-69. - doi: 10.3832/ifor 0911-007

Santi E, Maccherini S, Rocchini D, Bonini I, Brunialti G, Favilli L, Perini C, Pezzo F, Piazzino S, Rota E, Salerni E, Chiarucci A (2010). Simple to sample: vascular plants as surrogate group in a nature reserve. Journal for Nature Conservation 18: 2-11. - doi: 10.1016/j.jnc.2009.02.003

Santos-Silva C, Gonçalves A, Louro R (2011). Canopy cover influence on macrofungal richness and sporocarp production in montado ecosystems. Agroforestry Systems 82: 149-159. - doi: 10.1007/s10457-011-9374-7

Schmit JP, Mueller GM, Leacock PR, Mata JL, Wu QX, Huang YQ (2005). Assessment of tree species richness as a surrogate for macrofungal species richness. Biological Conservation 121: 99-100. - doi: 10.1016/j.biocon.2004.04.013

Similä M, Kouki J, Mönkkönen M, Sippola AL, Huhta E (2006). Co-variation and indicators of species diversity: can richness of forest-dwelling species be predicted in northern boreal forests? Ecological Indicators 6: 686-700. - doi: 10.1016/ j.ecolind.2005.08.028

Su JC, Debinski DM, Jakubauskas ME, Kindscher K (2004). Beyond species richness: Community similarity as a measure of cross-taxon congruence for coarse-filter conservation. Conservation Biology 18: 167-173. - doi: 10.1111/j.1523-17 39.2004.00337.x

Temunović M, Franjić J, Satovic Z, Grgurev M, Frascaria-Lacoste N, Fernández-Manjarrés JF (2012). Environmental heterogeneity explains the genetic structure of Continental and Mediterranean populations of Fraxinus angustifolia Vahl. PLoS ONE 7 (8): e42764. - doi: 10.1371/ journal.pone. 0042764

ter Braak CJF, Šmilauer P (2002). CANOCO reference manual and CanoDraw for Windows user's guide: software for canonical community ordination. Microcomputer Power 4.5, Ithaca, New York, USA, pp. 500. [online] URL: http:// library.wur.nl/WebQuery/clc/1722500

Tóth BB, Barta Z (2010). Ecological studies of ectomycorrhizal fungi: an analysis of survey me- 
thods. Fungal Diversity 45: 3-19. - doi: 10.1007/ s13225-010-0052-2

Tyler G (1992). Tree species affinity of decomposer and ectomycorrhizal macrofungi in beech (Fagus sylvatica L.), oak (Quercus robur L.) and hornbeam (Carpinus betulus L.) forests. Forest Ecology and Management 47: 269-284. - doi: 10.1016/0378-1127(92)90279-I

Twieg BD, Durall DM, Simard SW, Jones MD (2009). Influence of soil nutrients on ectomycor- rhizal communities in a chronosequence of mixed temperate forests. Mycorrhiza 19: 305316. - doi: 10.1007/s00572-009-0232-7

Virolainen KM, Ahlroth P, Hyvärinen E, Korkeamäki E, Mattila J, Päivinen J, Rintala T, Suomi T, Suhonen J (2000). Hot spots, indicator taxa, complementarity and optimal networks of taiga. Proceedings of the Royal Society B 267: 1143-1147. - doi: 10.1098/rspb.2000.1120

Zimmerman GM, Goetz H, Mielke PV (1985).
Use of an improved statistical method for group comparisons to study effects of prairie fire. Ecology 66: 606-611. - doi: 10.2307/1940409

Whitfield J (2007). Fungal roles in soil ecology: underground networking. Nature 449: 136-138. doi: 10.1038/449136a

Young TP (2000). Restoration ecology and conservation biology. Biological Conservation 92: 73-83. - doi: 10.1016/S0006-3207(99)00057-9 